\title{
THE SOCIAL AND PSYCHOLOGICAL FACTORS OF YOUTH'S SUICIDAL BEHAVIOUR
}

\author{
Yaroslav Riabchych ${ }^{l}$, Mariia Kapkan ${ }^{2}$ \\ ${ }^{I} P h D$, assistant Department of Developmental Psychology of Taras Shevchenko National University of Kyiv,
Kyiv (Ukraine) \\ ORCID ID: https://orcid.org/0000-0002-3216-5059 \\ ${ }^{2}$ Graduate student of General Psychology of Taras Shevchenko National University of Kyiv, Kyiv (Ukraine)
}

UDC: 159.316 .624

\begin{abstract}
The article examines socio-psychological factors influencing youth's suicidal behaviour in. The article provides theoretical and methodological substantiation and empirical verification of correlations of young people's suicidal behaviour with their psychological personal traits, identifies socio-psychological features of such behaviour, as well as provides an empirical analysis of individual psychological factors of suicidal ideation.

The authors propose a step-by-step model of the suicidal behaviour emergence and describe its main stages.

There are three groups of factors that provoke youth's suicidal behaviour.

It has been empirically proven that pre-suicidal behaviour is conditioned by many various factors. The most common of them are: expressed anxiety, frustration, aggression, rigidity, as well as changes in the attitude to one's own life and death.
\end{abstract}

Keywords: suicidal behaviour, suicidal ideation, social and psychological maladaptation, youth.

\section{INTRODUCTION}

Almost 12 thousand Ukrainians kill themselves annually according to the official data of the State Statistics Service of Ukraine. Ukraine belongs to the group of countries with a high suicidal level (more than 20 suicides per 100 thousand people) according to the World Health Organization (WHO).

Statistics indicate that youth have the second (after adolescents) suicide rate. Psychological shift from childhood to full adulthood takes place at this age. During this life period self-understanding is forming. It allows a person to adjust inner slef-assessment and find a balance between own position and that one which other people might have. Also the notion "ideal" is started to be correlated with own personal traits. In other words, the main psychological characteristic of youth is awareness of own personality and uniqueness. Young people often become aware that they incapable to reach the Self-ideal, which, in its turn, leads to intrapersonal intractable conflicts. In some moments such personal conditions can lead to the emergence of suicidal behaviour.

So, critical periods and certain characteristics of this age provoke the necessity for professional assistance and psychological support. Its goal is to provide preventive measures aimed at avoiding suicidal behaviour.

There were two main groups of contradictions in the history of suicide research. First, it was a contradiction of theoretical nature, due to the difference of scientific paradigms used to study the problem of suicidality.

The sociological trend was represented by S. Boy- 
DOI (Issue): https://doi.org/10.31108/1.2021.7.1

ko, K. German, Y. Gilinsky, E. Durkheim, O. Myagkov, I. Orlov, M. Popov, P. Sorokin, V. Tikhonenko, M. Halvaks, P. Schneider, P. Yunatskevich, etc. It focused on the awareness of suicidal behaviour and its conditioning by the degree of an individual's social integration.

The medical direction was represented by the works of V. Bekhterev, M. Brukhansky, P. Bulatsel, ZhE. Eskirol, P. Kovalevsky, A. Koni, A. Lichko, A. Likhachev, C. Lombroso, V. Rozanov, A. Chuprikov, etc. They significantly influenced the theory and practice preventing the development of suicidal tendencies. However, it should be noticed, that these works described only individuals with confirmed corresponding diagnoses of mental illness.

The psychological concepts of self-destructive behaviour also influenced significantly the studies on suicidal risk prevention. These concepts were proposed by A. Ambrumova, A. Bandura, L. Berkovitz, E. Grollman, D. Dollard, A. Maslow, K. Meninger, N. Miller, and A Rean, K. Rogers, N. Farberow, V. Frankl, Z. Freud, E. Fromm, E. Schneidman.

The contradictions at the scientific and methodological level exist due to a discrepancy between theoretical elaboration and practical effectiveness of the measures aimed at:

$\Rightarrow \quad$ reducing the risk of young people's suicidal behaviour;

$\Rightarrow \quad$ improvement of teachers' competence of in this;

$\Rightarrow \quad$ improvement of suicidal behaviour monitoring practice.

At the same time, individual and psychological determinants of suicidal behaviour have not investigated to the fullest extent.

Despite the fact that the psychological and pedagogical aspects of suicidal behaviour prevention are of particular importance recently, complex studies of such behavioural risks in youth are nearly absent in our country. The current state of the theory and practice preventing the risk of young people's suicidal behaviour shows is characterised by perversion, fragmentation and incompleteness of the psychological and pedagogical work with university students in crisis.

The study aim: to determine the peculiarities and factors of the emergence of youth's suicidal behaviour.

Tasks:
1. To form a model of young people's suicidal behaviour after analyzing contemporary national and foreign approaches.

2. To identify the main social and psychological determinants contributing to young people's suicidal behaviour.

Main material and its presentation. On the basis of theoretical review and our previous researches (Ryabchich, 2013), we have formulated suicidal behaviour as a sequential process of gradual suicidality formation, (Fig. 1). The root cause of suicidal behaviour is one's inability to adapt to changed social environment, which leads to conflicts with people around. They, in turn, cause objective or / and subjective social and psychological maladaptation.

Objective maladaptation is manifested as changed behaviour in the close social environment, a limited ability to perform successfully one's social functions or pathological behavioural transformations.

The subjective signs of maladaptation include a wide range of psychological and emotional disturbances from negatively coloured psychological feelings (anxiety, grief, emotional pain, insults, shame, indignation, anger, dysphoria etc.) to distinct psychopathological syndromes (asthenia, dysthymia, depression).

So, social and psychological maladaptation is not identical to the concept of illness. Such maladaptation appears at two levels: pathological and non-pathological. Nosological units, conditions, reactions and phases, which are well-known in clinical psychiatry, relate to the pathological level of maladaptation. The non-pathological maladaptation means one's deviated behaviour and feelings, related not to diseases, but to insufficient socialization, poor moral education, socially unacceptable attitudes, unexpectedly changed conditions of existence and life-style, broken important social relationships and communications, imitation of socially unacceptable behavioural patterns etc. (Ambrumova, 1978). Thus, a young person's behaviour begins to deviate from the norm because of these conditions.

The next step of suicidality formation is emerging deviant behaviour. Still, deviant behaviour alone is not a suicidal factor. The transition from the prepositioning phase to the suicidal one occurs at the so-called critical point, when an intractable intrapersonal conflict emerges. Such conflict is formed by two or more multidirectional tenden- 
DOI (Issue): https://doi.org/10.31108/1.2021.7.1

cies: the basic one - a young person's urgent necessity at the moment, and the other one - tendencies that hinders inner satisfaction.

Therefore, it is worth examining each of the stages separately and comparing them with each other in order to diagnose pre-suicidal behaviour. The achieved results can help to recognize the suicidal period timely.

We have also identified three groups of typical factors that influence young people's social and psychological maladaptation:

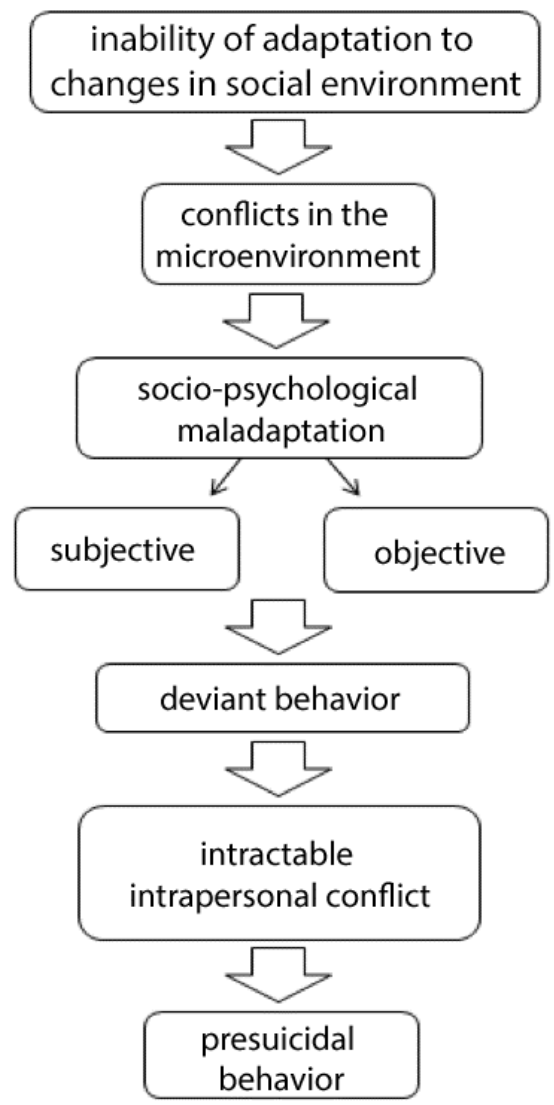

Fig. 1. Model of forming suicidal behaviour

General psychological features of suicides with non-pathological situational intentions, as well as people with borderline conditions: self-centeredness, autoaggression, personal pessimistic attitude to the future, paranoid personality of a suicidal individual and such peculiarities of the emotional sphere as depression and anxiety (Slut 1992).

Personal factors: emotional problems with peers, death of a significant person, breakup with a beloved one, interpersonal conflicts or a loss of meaningful relationship, discipline or law problems, prolonged victimization, frustra- tion with education and unsatisfied academic achievements, high educational demands concerning final exams, problems with employment and poor economic situation, financial problems, unwanted pregnancy, abortion and its consequences, AIDS or other sexually transmitted infections, serious physical illness;

Family factors: parental mental disorders, family members' addictive behaviour, suicides or suicidal attempts by the family members known from a family history, domestic violence, lack of attention and care for children in the family, poor relationships between family members, frequent quarrels between parents, constant emotional stress and high levels of aggression in the family, only one parent (divorce, death of one parent), too low or high expectations of parents for children, insufficient attention to parenting. The American psychologist D. Elkind believed that the main cause of suicide attempts and suicides was the pressure of parents on boys and girls in order them to be successful (Elkind, 1974)

Modern psychologists point to the frequent changes of residence, study, work; negative impact of the media and contemporary literature, online content as the causes of suicide in youth age.

So, we can talk about a wide range of factors that provoke the emergence and development of suicidal behaviour at youth. They influence the motive behind a suicide attempt. Unlike adolescence, which is characterized by demonstrative and affective forms of suicide, youth more often have real desire to die, here, so-called Freudian "Thanatos" might be seen, and they make attempts to solve actual life difficulties by leaving this life. Here, we can assume that a large part of young people's suicides are true and suicide attempts are characterized by an understanding of the committed act, prolonged crisis period that precedes suicide, as well as the stability of intentions (careful choosing of time and place, method of deprivation of life, etc.).

We conducted an empirical work in order to study this problem in 2018 and 2019, with a total sample of 120 people, 17-24 years old. The studied sample consisted of 89 girls and 31 boys. They were students of Kyiv higher educational institutions; 3 methods for determining the presence and predisposition to suicidal behaviour were applied. People who participated in the study were mentally healthy (during the study they were not registered by a psychiatrist), 
they filled in all proposed methods and on the falsehood scale of the Suicide Risk Test SR-45 (P.I. Yunatskevich) received a "passing" mark. The family composition was also taken into account: 89 people had both parents, 31 had only one parent.

\section{3 valid and reliable methods were used:}

1. "Suicide Risk Test SR-45" (P.I. Yunatskevich). People who have a propensity for suicidal reactions can be identified using this technique. The methods consists of 45 statements. There are 3 scales available for data analysis: suicidal tendency, falsehood scale, manifestation level and generalized suicidal susceptibility scores.

Suicidal reactions (Ambrumova, 1981) mean a certain type of a person's behaviour with a sufficient probability of forming a suicidal action in response to external physical or mental traumatic factors. Such reactions are typical for patients with mental disorders, as well as for mentally healthy people.

\section{The method determining propensity to suicidal} behaviour (M.V. Gorskaya). The purpose of this method is to identify an individual's predisposition to suicidal behaviour. It consists of 40 statements. Four scales are used to process the results: anxiety scale, frustration scale, aggression scale, rigidity scale.

3. "Suicidal Behaviour Questionnaire" (T. Vasek) is aimed at early diagnosis of suicidal behaviour, even before its actual manifestation. It determines the stage of a person's suicidal behaviour, the frequency of suicidal ideas, the presence of people around who tried or committed suicide and a respondent's attitude to suicide. Genetically predetermined properties of biochemical processes in the human body can have the decisive role in the formation of suicidal behaviour and is evidenced by the studies of families that had not any hereditary diseases that can provoke suicide. It is important to note that in the first generation of offspring of suiciders, the incidence of suicidal attempts and suicides is approximately 4 times higher than in the control group. The probability of hereditary transmission of suicidal behaviour is $12-18 \%$ in a perspective "parentschildren". The methods consists of 31 questions, where several options for the answer are offered. It contains two scales: the Suicide Scale as the main informative scale and the Attitudes to Life and Death. M. Kovach stated (Kovacs, 1997) that suicidality depends on two main factors: an atti- tude to life that can be positive and negative, and an attitude to death (both variants). A suicide is more likely at people who are negative about life and positive about death.

The sample was divided into three groups for comparative analysis of suicidal behaviour. The criterion for division was the Suicide Scale of the 'Suicidal Behaviour Questionnaire' and its comparison with the Suicidal Risk Test (SR-45 P.I. Yunatskevich) and the method determining propensity to suicidal behaviour (MV Gorskaya). In general, the groups were divided according to the Suicide Scale (questions \# 10-21) of the 'Suicidal Behaviour Questionnaire'. The structure of these questions and the scale allow establishing the frequency of suicidal ideas and stages of suicidal behaviour development.

The first group formed people who scored from 0 to 9 points for this scale; the second group included young people who answered "yes" to questions \# 10-18 (passive suicidal thoughts); the respondents creating the third group answered "yes" to questions \#19-21 (suicidal intentions and ideas).

As a result, three groups were identified, which differ by their level of suicidality:

1. The first group included young people without manifestations of suicidal behaviour.

2. The second group included youth with suicidal ideas. Boys and girls assigned to this group were characterized by an internal (passive) form of suicidal behaviour that is characterized by thoughts (ideas) about their deaths but was not developed into a conscious desire to take their own lives. They also had changes in mood, difficulties in communication, asocial behaviour, alcoholic excesses, and impulsive behaviour.

3. The third group included people with clearly defined suicidal intentions. They had an active form of suicidal behaviour, which included not only suicidal ideas but also meaningful planning and preparing of suicidal actions. This group included youth who assumed the possibility of suicidal attempt. The main characteristics of young people from this group were constant suicidal thoughts, suicidal statements; abrupt changes in behaviour, lifestyle; various forms of self-destructive behaviour, direct or indirect "goodbyes" to their beloved or families, inadequate forms of behaviour ("evil" calm, ideamotor inhibition, agitation).

Each of the selected groups was given its own 
name, which reflects the presence / absence of suicidality

Table 2 .

and its severity:

1. The "Norm" group, hereafter N, consisted of 91 people $(75.8 \%)$

2. The group of "Suicidal ideas", hereafter referred to as SI, consisted of 19 people (15.8\%).

3. The Group of "Suicidal Intentions", hereafter referred to as SIG, consisted of 10 people (8.3\%).

The gender characteristics of suicidality were:

1. Suicidal ideas are completely absent at $74.1 \%$ of boys ( 23 boys) and $76.4 \%$ of girls ( 68 girls);

2. There are expressed suicidal ideas at $25.8 \%$ of boys ( 8 people) and $12.3 \%$ of girls (11 people);

3. Suicidal ideas exist at $0 \%$ of boys (no boys) and $11.2 \%$ of girls (10 young ladies).

As it can be seen from the results, the distribution in the SI and SIG groups by gender is uneven. Therefore, a further study was conducted without gender division in order to evaluate the results objectively.

The average values for the 'Suicidal Behaviour Questionnaire' scales (SBQ) and Suicide Risk Test (SRT) for different groups are presented in Table 1 in order to determine the reliability of the respondents' division into groups.

Table 1.

Average values of groups by SBQ and SRT

\begin{tabular}{|l|l|l|l|l|}
\hline \multirow{2}{*}{ Indicators } & \multicolumn{3}{|c|}{ Average value } \\
\hline suicidality & $\mathrm{N}$ & $\mathrm{SI}$ & SIG \\
\hline attitude to life and death & 3,1 & 13,8 & 21,6 \\
\hline $\begin{array}{l}\text { the presence of persons with suicidal } \\
\text { behavior }\end{array}$ & 14,5 & 16,1 & 23,5 \\
\hline suicidal response rate * & 2,54 & 3,2 & 3,8 \\
\hline
\end{tabular}

Notes: * The lower the score, the higher the suicidal response rate.

In addition, the "Method determining propensity to suicidal behaviour" (DPSB) was also used. We analyzed the results obtained by internal methodology based on the above identified groups (Table 2).

We should start with the anxiety indicator; it has almost the same value in the $\mathrm{N}$ and SI groups and 3 points higher in the group of Suicidal intentions (SIG). The frustration differs in the $\mathrm{N}$ and SI groups only by one point. At

Group results DSSB

\begin{tabular}{|l|l|l|l|}
\hline Indicators & \multicolumn{2}{|l|}{ Average value } & $\mathrm{H}$ \\
\hline & $\mathrm{H}$ & $\mathrm{Cl}$ & 13,2 \\
\hline \begin{tabular}{l} 
anxiety \\
\hline
\end{tabular} & 7,05 & 9,7 & 4,5 \\
\hline frustration & 10,1 & 8,7 & 10,3 \\
\hline $\begin{array}{l}\text { aggression } \\
\text { rigidity }\end{array}$ & 10,7 & 10,1 & 12,7 \\
\hline $\begin{array}{l}\text { propensity } \\
\text { for suicidal } \\
\text { behavior }\end{array}$ & 4,5 & 9,5 & 46,8 \\
\hline
\end{tabular}

the same time, the average values of the Suicidal Intentions group are higher on 5 points.

Aggression does not vary between groups: the $\mathrm{N}$ and SI groups have the same average values and the value for the Suicidal Intention group is larger by only two tenths. The DPSB rigidity indicator does not vary between groups also: the lowest one is in the SI group and the highest in the group of Suicidal Intentions. Average values for suicidal behaviour are: this value is the lowest in the Norm group and indicates the low level of suicidal behaviour; the tendency to suicidal behaviour in the SI group is also low; and the average value in the group Suicidal Intentions, as the table shows, is the highest compared to other groups and it means that such level of suicidal behaviour requires the attention of professionals.

We used Pearson's correlation coefficient analysis in order to analyze correlations among individual psychological characteristics of people with suicidal behaviour. The analysed correlations of DPSB, SBQ, and SRDT methods showed that the strongest correlations exist between the suicidality scale and life-and-death attitude scales, suicidal behaviour predisposition (by DPSB) and the Suicidal Risk Level scale (by the SBQ method).

So, the analysed correlations between the studied indicators suggests that suicidality can appear because of some personal traits, such as mood instability, aggressive behaviour, frustration, antisocial behaviour, irritability, rigidity of thinking, negative feelings, fears, problems with the definition of sexual orientation, etc., and such personal aspect as an attitude to life and to death, which is determined mainly by relationships in society.

A multiple regression analysis was conducted for 
DOI (Issue): https://doi.org/10.31108/1.2021.7.1

statistically significant grouping of the data obtained during the study, so that a logical and consistent model of factors influencing suicidality and related factors was created and substantiated. The main purpose of regression analysis was

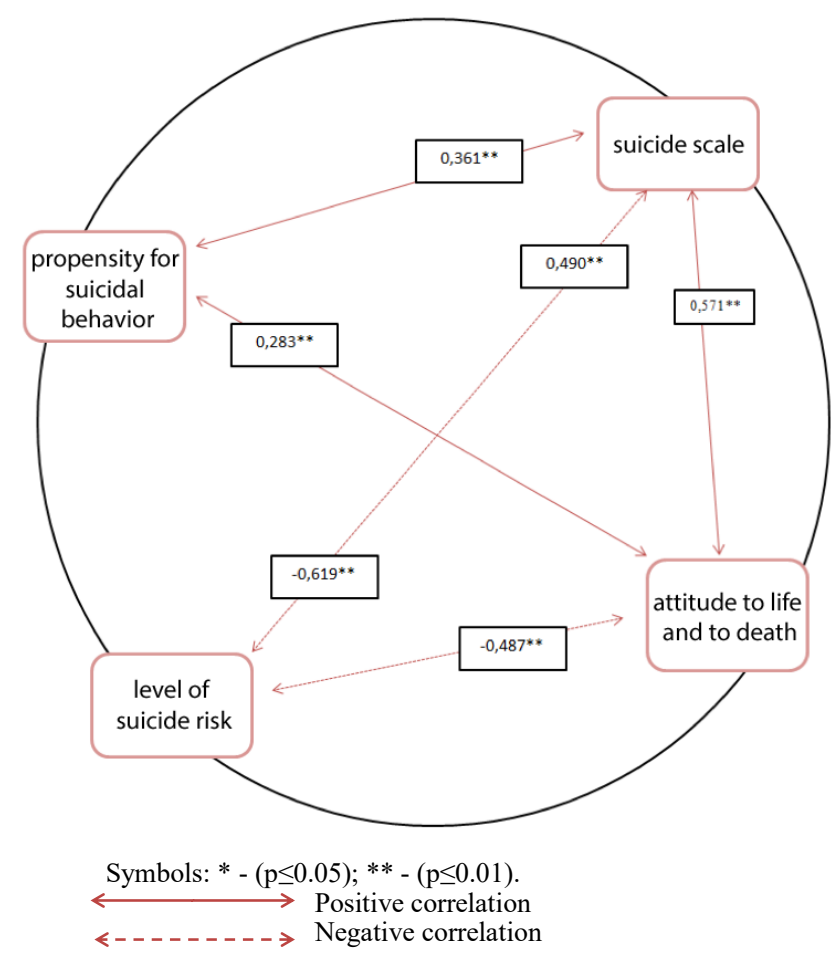

Figure 2. Correlative linkages of the method for the Determination of Suicidal Behavior (DSSB), the Suicide Test $C P$ - 45 and the Suicidal Behavior Questionnaire (SBQ)

to determine the dependent and independent variables.

The most significant coefficients for our study were:

1. $\mathrm{R}$ is a multiple correlation coefficient. It is a measure of the association of the entire set of independent variables with the dependent variable;

2. R2 (R-quadrant) is the coefficient of determination. It characterizes the proportion of the dependent variable variance due to the influence of the independent va-
Volume 7 Issue 1 (45) 2021

riables;

3. $F$ is a coefficient that reflects how much the dependent variable variance is explained by our regression model.

It is worth noting that we selected for the analysis only variables with the strongest correlations. Based on this selection, we found possible predictors for the dependent variable.

The dependent variable was the suicide rate. Using the correlation matrix, we chose 3 predictors: life and death attitudes, suicidal behaviour and suicidal risk.

Obtained R- quadrant for our model equalled 0.483, thus $48.3 \%$ of the variance for "suicide rate" variable is attributable to the impact of life and death variables, propensity to suicidal behaviour and the level of suicidal risk. Using the Durbin-Watson test we checked the absence of autocorrelations (the ratio should be in the range $0-4$, ideally it should be about 2). In our case the Durbin-Watson coefficient was 1.787 , so we can say that there were no autocorrelations.

In addition we analyzed the statistical significance with F-Fisher criterion, which indicated a strong links of the dependent variable with all three independent variables as well as with each variable separately.

Our next step was to test data for multicollinearity or correlations between the independent variables (Table 3). VIF was less than 5 and this was an evidence of absent multicollinearity. If we are talking about tolerance, the values are close to 1 , which indicates that the analyzed predictors were independent of other predictors.

Table 3 presents data that have allowed us to construct a regression model that describes the contribution to the suicidality rate for the overall study sample. So the

Table 3.

\section{F-Fisher criteria and its significance}

\begin{tabular}{|c|c|c|c|c|c|c|c|c|}
\hline \multirow{2}{*}{\multicolumn{2}{|c|}{ Model }} & \multicolumn{2}{|c|}{$\begin{array}{l}\text { Non-standardized } \\
\text { coefficients }\end{array}$} & \multirow{2}{*}{$\begin{array}{c}\begin{array}{c}\text { Standardized } \\
\text { coefficients }\end{array} \\
\text { beta } \\
\end{array}$} & \multirow[b]{2}{*}{$t$} & \multirow[b]{2}{*}{ value } & \multicolumn{2}{|c|}{ Collinearity statistics } \\
\hline & & B & mistake & & & & tolerance & VIF \\
\hline \multirow[t]{4}{*}{1} & (constant) & 12,935 & 3,928 & & 3,293 & 001 & & \\
\hline & $\begin{array}{l}\text { attitude to life and } \\
\text { death scale }\end{array}$ &, 264 & .115 &, 180 & 2,287 & .024 & .717 & 1,395 \\
\hline & $\begin{array}{l}\text { propensity for } \\
\text { suicidal behavior }\end{array}$ & , 162 & .047 & .240 & 3,443 &, 001 &, 920 & 1,087 \\
\hline & level of suicide risk & $-4,284$ & 658 &,- 498 & $-6,511$ & ,000 & ,763 & 1,310 \\
\hline
\end{tabular}

*dependent variable: suicide scale 
DOI (Issue): https://doi.org/10.31108/1.2021.7.1

equation looks like this:

Suicidality $=12,935+0.264 *$ (Attitude to Life and Death $)+\mathbf{0 . 1 6 2} *$ (Addicted to Suicidal Behavior $)-\mathbf{4 . 2 8 4}$ * (Suicidal Risk Level).

Next (see Fig. 3 and 4), we provide graphical illustrations of the extent to which suicidality is influenced by the examined indicators.

Taking all above into account, we can argue that suicidality can occur primarily because of intrapersonal states such as anxiety, fear, frustration, aggression, which also give rise to a suicidal tendency. Also, we should not forget about the social determinants, which primarily affect the development of a personality and such important aspects of our everyday life as views on life and death. A person's stable mental state, inner desires and goals are the result of the atmosphere in the family and other social institutions.

\section{CONCLUSIONS}

1. The conceptual foundations of the determinants of young people's suicidal behaviour have been formed as a result of the performed theoretical analysis. A step-by-step model of suicidal behaviour is described. Three groups of typical factors have been also identified. These factors influence young people's social and psychological maladaptation: general psychological features of suicides; personal factors; family factors.

2. Three main groups of young people were identified based on obtained empirical data. They differ by their degrees of suicidality.

The first group included individuals without any

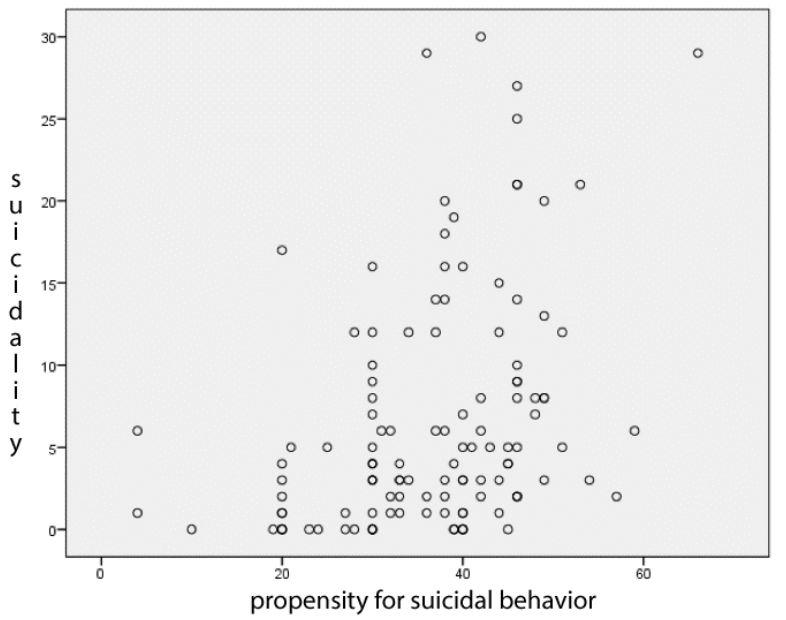

Fig. 3. Impact of suicidal tendency on the suicidality, $S B Q$ method (for the total sample) manifestations of suicidal behaviour $(75.8 \%$ of the total sample).

The second group included youth with suicidal ideas (15.8\% of the total sample). This group were characterized by a passive (internal) form of suicidal behaviour. These people were characterized by ideas (thoughts) of committing a suicide, but they did not formulate it into a truthful conscious desire to take their lives because of their "emotional readiness". These people were also characterized by such personality traits as anxiety and depressiveness, mood changes, problems in communication, emotional disorders, asocial acts, alcohol excesses, impulsive behaviour.

The third group $(8.3 \%)$ included young people with clearly defined suicidal intent, in other word, an active (internal) form of suicidal behaviour with not only suicidal ideas, but also thoughtful planning and preparation of suicidal actions.

3. The empirical study revealed that suicidal behaviour can occur as a result of psychological health deterioration - anxiety, frustration, aggression, as well as because of changed attitudes to life and death. It happens under possible influence of the close environment or reassessment of self- concept. The respondents form the group of Suicidal Intentions expressed anxiety and high personal frustration. The causes for frustration can be real or imagined obstacles that impede the goal achievement. Aggression in the analysed empirical data was at almost the same level for all three groups. Such an indicator manifested increased psychological activity. The highest level of rigidity was ob-

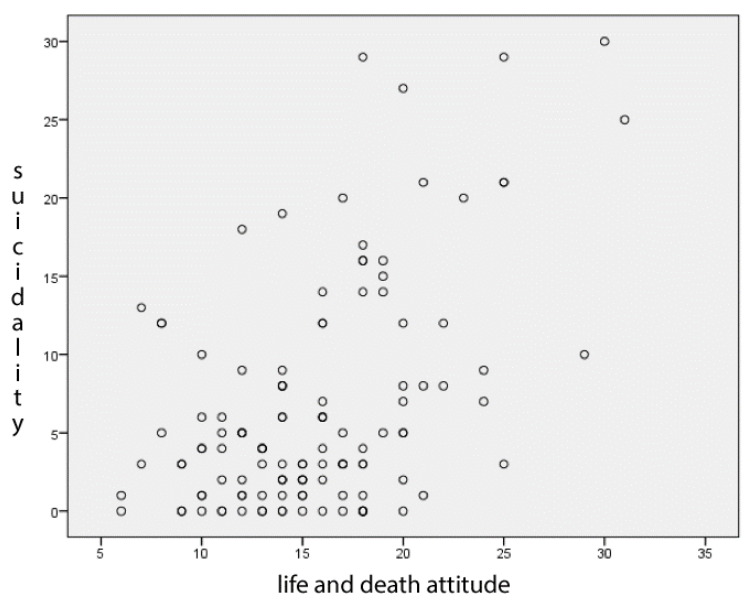

Pic. 4. Impact of the indicator 'life and death attitude' on the suicidality, $S B Q$ method (for the total sample) 
DOI (Issue): https://doi.org/10.31108/1.2021.7.1

served in the group of Suicidal Intentions, such rigidity was associated with complications existing during implementation of significant activities.

\section{References:}

Ambrumova, A. (1978). Individualno-psihologicheskie aspektyi suitsidalnogo povedeniya [Individual psychological aspects of suicidal behavior] Moscow: Aktualnyie problemyi suitsidologii. [in Russian]

Ambrumova, A. (1981). Rol lichnosti v problemah suitsida [The role of personality in suicide problems]. Moscow : Aktualnyie problemyi suitsidologii. pp. 73-93. [in Russian]

Elkind, D. (1974). A Sympathetic Understanding of the Child: Birth to Sixteen - Publisher. Allynand Bacon. [in English]

Kovacs, M., Beck, A. T. (1977). The wish to die and the wish to live in attempted suicide. Journal of Clinical Psychology. - No 33. pp. 361-365. [in English]

Ryabchich, I. (2013). Sotsialno-psihologichni chinniki presuyitsidalnoyi povedinki pidlitkIv [Socio-psychological factors of teenagers pre-suicidal behavior]. Taras Shevchenko National University of Kyiv, Kyiv. [in Ukrainian]

Slutskyi, A. (1992). Nekotoryie psihologicheskie aspektyi povedeniya suitsidentov [Some psychological aspects of suicidal behavior]. Moscow. Psihologicheskiy zhurnal, 13, 1. [in Russian]

\section{Yaroslav Riabchych}

PhD in Psychological Sciences, assistant professor of the Department of Developmental Psychology, Taras Shevchenko National University of Kyiv, Kyiv (Ukraine)

\section{Mariia Kapkan}

Graduate student of the Psychology Department, Taras Shevchenko National University of Kyiv, Kyiv (Ukraine)

\section{THE SOCIAL AND PSYCHOLOGICAL FACTORS OF YOUTH'S SUICIDAL BEHAVIOUR}

\section{ABSTRACT}

The article highlights the current view on social and psychological determinants of youth's suicidal behaviour. The modern science still does not have a unified point of view on suicidal behaviour. The corresponding terminology is amorphousness and its concept is uncertain.

Volume 7 Issue 1 (45) 2021

It is generally accepted that suicidal behaviour depends on many factors, has different motives and goals and exists in certain and extreme conditions.

The authors present their own model of suicidal behaviour that includes the following main factors leading to suicidal behaviour: social and psychological maladaptation, deviant behaviour and unresolved intrapersonal conflicts.

We have identified four groups of factors affecting young people's social and psychological maladaptation:

- General psychological features of a suicider having non-pathological situational intentions, as well as people having borderline states;

- Personal factors;

- Family factors;

- Other life factors: a changed place of residence, study or work; negative influence of mass-media, modern literature, Internet sites with certain content, etc.

A set of standardized and tested methods was selected to examine social-psychological factors of young people's pre-suicidal and suicidal behaviour: 3 methods studying susceptibility to suicidal reactions, suicidal behaviour and the diagnosis of suicidal behaviour before its manifestation.

The sample consisted of 120 young people (89 girls and 31 boys). Their families were also taken into account: 89 respondents had both parents, 31 had only one of parents.

The sample was divided into three groups for comparative analysis of suicidal behaviour. The division criterion of was the suicide indicator from the Suicide Behaviour Questionnaire that was compared with the results of the Suicide Risk Test (SR-45, P.I. Yunatskevich) and the method determining propensity to suicidal behaviour (M.V. Gorskaya).

The statistical methods were used to process the obtained data: Pearson's correlation coefficient was used to analyze relations between individual psychological characteristics with suicidal behaviour; a multiple regression analysis was performed for data grouping; statistical significance was checked by the F-Fisher test.

The performed empirical study has revealed that suicidal behaviour can appear because of deteriorated personal psychological health - anxiety, frustration, aggression 
Также были выделены четыре группы типичand changes in attitudes toward life and death under environmental influences or because of overestimated selfconcept. The respondents having suicidal intentions were characterized by severe anxiety and high frustration as the consequences of personal disappointment, inability to overcome real or imagined obstacles preventing goal achievement.

Aggression was almost the same for all three examined groups, thus this indicator showed rather increased psychological activity. The highest rigidity was observed at the respondents having suicidal intentions; such rigidity was associated with complications existing during implementation of significant activities.

Keywords: suicidal behaviour, suicidal ideation, social and psychological maladaptation, youth.

\section{Рябчич Ярослав Евгеньевич}

Кандидат психологических наук, дочент кафедры психологи развития Киевского наџионального университета имени Тараса Шевченко, 2. Киев (Украина)

\section{Капкан Мария Евгеньевна}

Магистр факультета психологии Киевского начионального университета имени Тараса Шевченко, г. Киев (Украина)

\section{СОЦИАЛЬНО-ПСИХОЛГИЧЕСКИЕ ФАКТОРЫ СУИЦИДАЛЬНОГО ПОВЕДЕНИЯ В ЮНОШЕ- СКОМ ВОЗРАСТЕ}

\section{АННОТАЦИЯ}

В статье представлено современный взгляд на проблемы социально-психологических детерминант суицидального поведения в юношеском возрасте, раскрыто то, что в современной науке отсутствует единая точка зрения на понимание суицидального поведения. Исследования в данной области отличает терминологическая аморфность и концептуальная неопределенность. Общепринятым есть то, что суицидальное поведение зависит от множества факторов, проявляется в особенных неопределенных условиях и обусловлено разными мотивами и целями.

Была представлена авторская модель возникновения суицидального поведения. В модели рассматриваются основные факторы приводящие к формированию суицидальности, среди которых: социальнопсихологическая дезадаптация, девиантное поведение и неразрешённые внутренние личностные конфликты. ных факторов влияющих на социальнопсихологическую дезадаптацию людей юношеского возраста: цидента с непатологическими ситуационными намерениями, а также лиц с пограничными состояниями;

- Личностные факторы;

- Семейные факторы;

- Независимые факторы: изменение места жительства, учебы, работы; негативное влияние СМИ; влияние современной литературы, интернет-платформы с определенным контентом и тому подобное.

Подобрано батарею стандартизированных и апробированных методик, позволяющих диагностировать социально-психологические факторы пресуицидального и суицидального поведения юношей. Диагностический инструментарий содержит 3 методики для исследования склонности суицидальным реакциям, склонность к суицидальному поведению и диагностики суицидального поведения до манифестации.

В выборку вошли лица юношеского возраста общим количеством 120 респондентов, среди которых 89 девушек и 31 юношей. Также учитывался состав семьи - в 89 исследуемых имеются оба родителя, в 31 один из родителей.

Для сравнительного анализа суицидального поведения выборка была разделена на три группы. Критерием деления выступал показатель выраженности суицидальности «Опросника суицидального поведения» и сравнение с результатами теста на выявление суицидального риска (СР-45 П.И. Юнацкевич) и методики определения склонности к суицидального поведения (М. В. Горская).

Для обработки полученных данных использовались методы математического анализа: анализ связи индивидуально-психологических особенностей лиц с суицидальным поведением, был использован корреляционный анализ по коэффициенту корреляции Пирсона; с целью статистически значимого группирования данных было проведено множественный регрессионный анализ; уровень статистической значимости был проверен критерием F-Фишера.

В результате проведенного эмпирического
- Общие психологические особенности суи- 
DOI (Issue): https://doi.org/10.31108/1.2021.7.1

исследования выявлено, что суицидальные поведение может возникать как следствие ухудшение личностного психологического здоровья - появление тревоги, фрустрации, агрессии, а также неоднозначного (специфического) отношения жизни и к смерти, в результате определенного воздействия окружения или переоценки Я-концепции. Участникам группы «Суицидальные намерения», присущи выраженная тревожность и высокие показатели фрустрации - это последствия личностного разочарование, которое возникает в результате реальных или мнимых препятствий мешающим достижению цели.

Мера агрессии, была выражена почти на одинаковом уровне всех трех групп. Такой показатель в большей степени проявляет повышенную психологическую активность. Самый высокий уровень проявления показателя ригидности наблюдался в группе «Суицидальные намерения», который был связан с осложнениями значимой деятельности.

Ключевые слова: суицидальные поведение, суицидальные идеации, социально-психологическая дезадаптация, юношеский возраст.

\section{Рябчич Ярослав Свгенович}

Кандидат психологічних наук, дочент кафедри психологї̈ розвитку Київського національного університету імені Тараса Шевченка, м. Київ (Украӥна)

\section{Капкан Марія Свгенівна}

Магістр факультету психології Київського національного університету імені Тараса Шевченка, м. Киї (Украӥна)

\section{СОЦІАЛЬНО-ПСИХОЛОГІЧНІ ЧИННИКИ СУЇЦИДАЛЬНОЇ ПОВЕДІНКИ В ЮНАЦЬКОМУ ВІЦІ}

\section{АНОТАЦІЯ}

У статті висвітлено сучасний стан проблеми соціально-психологічних детермінант суїцидальної поведінки юнацтва, окреслено що в сучасній науці досі відсутня єдина точка зору на сутність суїцидальної поведінки. Дослідження в даній сфері вирізняє термінологічна аморфність і концептуальна невизначеність.

Загальновизнаним є лише те, що суїцидальна поведінка залежить від багатьох чинників, проявляється в особливих екстремальних умовах та обумовлена різними мотивами і цілями.

Була представлена авторська модель виникнення суїцидальної поведінки. В моделі розглядаються основні фактори що призводять до формування суїцидальності, серед яких: соціально-психологічна дезадаптація, девіантна поведінка та невирішальний внутрішньо особистісний конфлікт.

Також були виділені чотири групи типових чинників які впливають на соціально-психологічну дезадаптацію людей юнацького віку: Загальні психологічні особливості суїцидентів із непатологічними ситуаційними намірами, а також осіб із прикордонними станами; Особистісні чинники; Сімейні чинники;бНезалежні чинники: зміна місця проживання, навчання, роботи; негативний вплив ЗМІ; вплив сучасної літератури, інтернет-платформи 3 певним контентом тощо.

Підібрано батарею стандартизованих та апробованих методик, що дозволяють діагностувати соціально-психологічні чинники пресуїцидальної та суїцидальної поведінки юнаків. Діагностичний інструментарій містить 3 методики для дослідження схильності суїцидальних реакцій, схильності до суїцидальної поведінки та діагностики суїцидальної поведінки ще до ії маніфестації.

Вибірку склали особи юнацького віку загальною кількістю 120 респондентів, серед яких 89 дівчат та 31 хлопців. Також враховувався склад родини - у 89 досліджуваних наявні обидва батьки, у 31 - один з батьків.

Задля порівняльного аналізу суїцидальної поведінки вибірку було поділено на три групи. Критерієм поділу виступав показник вираженості суїцидальності за «Опитувальником суїцидальної поведінки» та порівняння з результатами тесту на виявлення суїцидального ризику (СР-45 П.І. Юнацкевич) та методики визначення схильності до суїцидальної поведінки (М. В. Горська).

Для обробки отриманих даних використовувались методи математичного аналізу: задля аналізу зв'язку індивідуально-психологічних особливостей осіб із суїцидальною поведінкою, був використаний кореляційний аналіз за коефіцієнтом кореляції Пірсона; з метою статистично значущого групування даних було 
проведено множинний регресійний аналіз; рівень статистичної значущості був перевірений критерієм FФішера.

В результаті проведеного емпіричного дослідження виявлено, що суїцидальні поведінка може виникати як наслідок погіршення особистісного психологічного здоров'я - поява тривожності, фрустрації, агресії, а також зміни ставлення до власного життя та до смерті, в результаті певного впливу оточення або переоцінки Я-концепції. Учасникам групи «Суїцидальні наміри», притаманна виражена тривожність та високі показники фрустрації - це наслідки особистісного розчарування, яке виникає у результаті реальних або уявних перешкод, які заважають досягненню повної мети. Міра агресії була виражена майже на однаковому рівні усіх трьох груп. Такий показник більшою мірою виявляє підвищену психологічну активність. Найвищий рівень прояву показника ригідності спостерігався у групі «Суїцидальні наміри», що був пов'язаний з ускладненнями значущої діяльності.

Ключові слова: суїцидальні поведінка, суїцидальні ідеації, соціально-психологічна дезадаптація, юнацький вік.

\section{How to cite (як цитувати):}

Riabchych Y., Kapkan M. (2021). SOCIAL AND PSYCHOLOGICAL FACTORS OF SUICIDAL BEHAVIOR OF YOUTH. PSYCHOLOGICAL JOURNAL, 7 (1), 9-19. https://doi.org/10.31108/1.2021.7.1.1 